\title{
Trials of Local Microorganism Composition (Mol) Toward Growth and Production Plant Lettuce (Lactuca Sativa)
}

\author{
Erwin Pane, Marwan Marwazi \\ Agrotechnology Study Program, Faculty of Agriculture Universitas Medan Area, Medan, Indonesia \\ erwinpane60@gmail.com
}

\begin{abstract}
Experiments of Various Local Microogranism Composition (MOL) Against Growth and Production of Lettuce (Lactuca sativa). This study aims to determine the effect of giving various MOLs to the growth and production of lettuce (Lactuca sativa). The design used in this study was a Non Factorial Randomized Block Design (RBD) with MOL composition treatment factors, consisting of 4 levels of treatment, namely: $M O=$ control, $M 1=1 / 4 \mathrm{~kg}$ papaya + ar palm sugar +2 L coconut water +2 L rice washing water, $M 2=$ $1 / 4 \mathrm{~kg}$ papaya $+1 / 4$ palm sugar +2 L coconut water +2 L rice washing water $+1 / 4 \mathrm{~kg}$ bamboo shoots, and M3 = 1/4 kg papaya $+1 / 4$ palm sugar +2 L coconut water +2 L water rice washing $+1 / 4 \mathrm{~kg}$ of maja fruit, and repeated 6 times. The parameters observed in this study were plant height, number of leaves, root length and wet weight of the harvest. The results showed that the treatment of various MOL compositions did not significantly affect the growth and production of lettuce plants.
\end{abstract}

Keyword: MOL; lettuce

\section{Introduction}

The natural condition of Indonesia makes it possible to cultivate various types of vegetable plants, both local and originating from abroad. From the climatological aspects, Indonesia is very potential in the business of vegetable business. Agricultural products have increased especially in vegetable commodity commodities such as lettuce. Apart from perannutrisinya, vegetables occupy a special place in the agricultural system because the method of exploitation is very intensive. Vegetables are generally harvested in fresh form (with high water content), the results are cultivated properly (Widodo et.al, 2010).

Lettuce plants are well known by the people of Indonesia. People who consume lettuce vegetables have recently shown an increase, because of the ease with which these vegetables are found in the market. Lettuce is a vegetable that has commercial value and a pretty good prospect. Judging from the climatological aspects, the latest aspects, economical and business, lettuce is worth trying to meet the high consumer demand and the international market opportunities are quite large (Haryanto et.al, 2003).

Lettuce leaves are rich in antioxidants such as beta-carotene, folate and lutoin and contain indole, which is effective in protecting the body from cancer. The content of natural fibers can maintain the health of digestive organs. The diversity of chemicals it contains makes lettuce a multichat plant. It can also function as a blood purifier, overcome coughing, inflammation of the skin, insomnia and disturbance of hemorrhoids (Wahyudi, 2003).

The need for lettuce commodities is increasing in line with the level of public awareness of the importance of family nutrition. Lettuce has a function as a body building agent, with enough nutrients and vitamins and is good for public health. Consuming these vegetables regularly every day in sufficient quantities can support and maintain human physical health (Aziz, 2006).

According to Teoteot (2007) the benefits of lettuce for body health is to help reduce the risk of heart problems and stroke, reduce the risk of cancer, reduce the risk of cataracts, 
help reduce the risk of spina bifda (a type of venereal disorders in the spine), help digestion work and liver health, reduce anemia and help relieve insomnia due to nerve tension.

The problem in agriculture today including lettuce cultivation is the use of very high chemicals, both for fertilization, growth booster and controlling pests, diseases and weeds. Chemicals are generally easy to apply so they can poison the environment and human health. Moreover, the process of washing vegetables that are not perfect also need to watch out for. Some chemicals in pesticides cannot be lost even if washed. Therefore, vegetables and fruits should be washed in running water. Especially for raw vegetables such as lettuce, to be more safe lettuce vegetables are washed in boiled water to avoid infectioncausing bacteria (Sidauruk, 2016).

The survey results at the vegetable planting center showed that the most dominant farmers controlled pests with synthetic insecticides with spraying intensity more than 6 times during one growing season and the use of high chemical fertilizers (Sidauruk, 2016).

In order to reduce the use of high synthetic fertilizers in vegetable cultivation, it requires a wise and safer action for health and the environment, but the production costs remain low. The best solution is to plant with an organic farming system that is planting using organic materials that are safe for the environment, such as the use of manure, compost, soil fertility bacteria and the use of local micro-organisms / MOL (Pracaya, 2002).

Liquid organic fertilizer contains several nutrients and substances needed by plants. These substances are derived from the organic material used in its manufacture. These substances consist of minerals, both macro and micro, amino acids, growth hormones and microorganisms. The content of substances and nutrients in balanced conditions so that it can spur plant growth (Pranata, 2004).

The use of bamboo shoots and maja fruit in this study is intended as a source of bacteria (microorganisms) that are very important for plants, including Rhizobium sp., Azosprillium sp., Pseudomonas sp. Bacillus sp. and phosphate solvent bacteria.

This study aims to determine the effect of giving various MOLs to the growth and production of lettuce (Lactuca sativa).

Based on the background above, the authors are interested in conducting research on lettuce plants with the title "Experiments of Various Micro Composition of Local Organisms (MOL) Against Growth and Production of Lettuce Plants (Lactuca sativa)".

\section{Research Method}

The study was conducted in the Experimental Field of the Faculty of Agriculture, University of Medan Area, located at Jalan Kolam No. 1 Medan Estate, Percut Sei Tuan sub-district with a height of about $12 \mathrm{~m}$ above sea level, with a flat topography.

This research was conducted using a non factorial randomized block design consisting of 4 treatments and 6 replications. The treatment application of MOL liquid organic fertilizer as follows: $\mathrm{M} 0=$ Control; $\mathrm{M} 1=1 / 4 \mathrm{~kg}$ papaya $+1 / 4 \mathrm{~kg}$ palm sugar $+2 \mathrm{~L}$ coconut water $+2 \mathrm{~L}$ rice washing water; $\mathrm{M} 2=1 / 4 \mathrm{~kg}$ papaya $+1 / 4 \mathrm{~kg}$ palm sugar $+2 \mathrm{~L}$ coconut water $+2 \mathrm{~L}$ rice washing water $+1 / 4 \mathrm{~kg}$ bamboo shoots; and $\mathrm{M} 3=1 / 4 \mathrm{~kg}$ papaya + $1 / 4 \mathrm{~kg}$ palm sugar $+2 \mathrm{~L}$ coconut water $+2 \mathrm{~L}$ rice washing water $+1 / 4 \mathrm{~kg}$ maja fruit.

If the results of this study have a significant effect, then further testing is done with Duncan's distance test (Gomez and Gomez, 2005).

The parameters observed in this study were plant height $(\mathrm{cm})$, number of leaves (strands), root length $(\mathrm{cm})$ and wet harvest weight $(\mathrm{g})$. 


\subsection{Research Implementation}

a. Preparation for Planting Media

- Making beds

Making beds is done before planting by cleaning and tidying the land from weedssugar and other impurities, carried out land management by repairing the soil or digging the soil.

- Seeding and Seeding Media

After the planting area has been sanitized, a seedling media consisting of soil, sand and compost is made in a ratio of 1: 1: 2 . While the seedlings are made measuring $1 \mathrm{~m} \times 1 \mathrm{~m}$ and then planting lettuce seeds in the seed media in each planting hole in the nursery beds.

\subsection{Transplanting}

Seedlings that are 2 weeks old are transferred to the beds carefully done and cultivated so that the roots and seedling media are not damaged, each bed planted with nine plants.

\subsection{Maintenance}

- Sprinkling

Watering is done twice a day, namely in the morning and evening, adjusted to the needs of plants from the beginning until the plants are ready to harvest.

- Thinning

After the seeds are around 7 days old and the plants have adapted to the new planting medium, thinning is carried out by pulling out one lettuce plant so that each bed only has one plant.

- Fertilization

At the first fertilization is done by giving liquid fertilizer (MOL) $20 \mathrm{cc} / \mathrm{L}$ of water which is applied at the 2nd week.

\subsection{Harvesting}

Harvesting of lettuce plants is carried out if the lower lettuce leaves begin to touch the soil, which is 30 days after planting. Harvesting is done by pulling all parts of the plant by hand.

\section{Result and Discussion}

\subsection{Plant Height}

The results of statistical data analysis on the variance list showed that the treatment of various MOL compositions did not significantly affect the height of the lettuce plant.

Table 1. Effect of MOL Composition Data on Plant Height (cm) Age 5 MST

\begin{tabular}{ccc}
\hline Treatment & Total & Average \\
\hline $\mathrm{M}_{0}$ & 85.11 & 14.19 \\
$\mathrm{M}_{1}$ & 90.14 & 15.02 \\
$\mathrm{M}_{2}$ & 84.37 & 14.06 \\
$\mathrm{M}_{3}$ & 93.07 & 15.51 \\
\hline
\end{tabular}

Source: Data processed (2015). 
The relationship between the composition of MOL with plant height aged 5 MST can be seen in Figure 1.

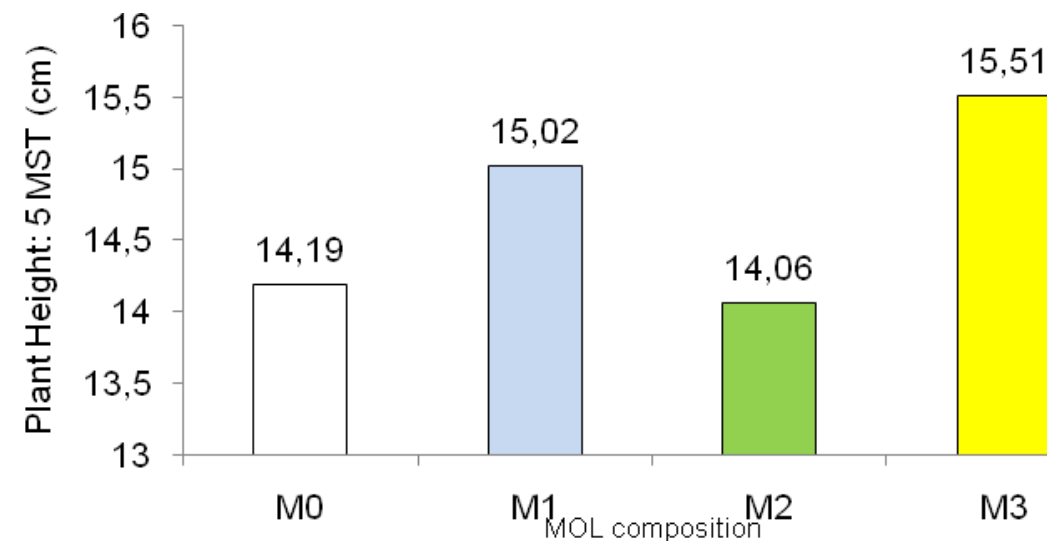

Figure 1. Relationship Diagram Between MOL Composition and Average Height of Lettuce Age 5 MST

From the figure above it appears that the M3 treatment is the treatment with the highest plant height, which is $15.51 \mathrm{~cm}$.

\subsection{Number of Leaves (strands)}

The results of statistical data analysis on the variance list showed that the treatment of various MOL compositions did not significantly affect the number of lettuce plants.

Table 2. Data on the Effect of MOL Composition on the Number of Leaves (strands) Aged

\begin{tabular}{ccc} 
& 5 MST & \\
\hline Treatment & Total & Average \\
\hline$M_{0}$ & 42.01 & 7.00 \\
$M_{1}$ & 39.33 & 6.56 \\
$M_{2}$ & 36.33 & 6.06 \\
$M_{3}$ & 43.67 & 7.28 \\
\hline
\end{tabular}

The relationship between the composition of MOL with the number of leaves aged 5 MST can be seen in Figure 2.
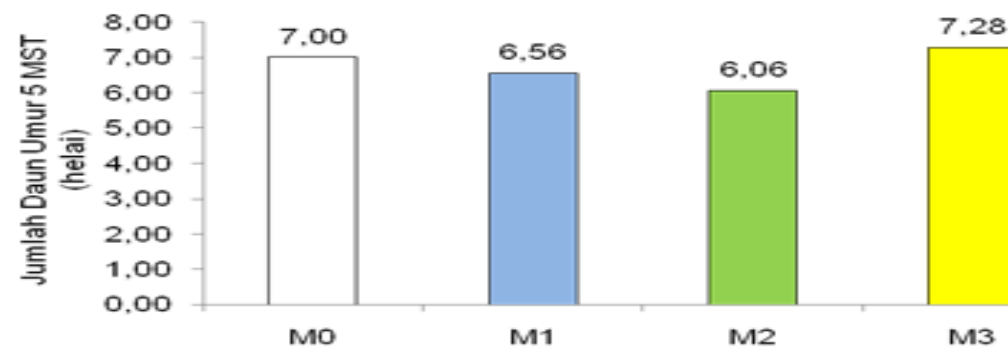

'Mol Composition

Figure 2. Relationship Diagram Between MOL Composition and Average Number of Leaves of Lettuce Age 5 MST

From the picture above it appears that the M3 treatment is the treatment with the highest number of leaves, which is 7.28 strands. 


\subsection{Root Length (cm)}

The results of statistical data analysis on the variance list showed that the treatment of various MOL compositions did not significantly affect the root length of the lettuce plants.

Table 3. Data on the Influence of MOL Composition on Root Length (cm) Age 5 MST

\begin{tabular}{ccc}
\hline Treatment & Total & Average \\
\hline $\mathrm{M}_{0}$ & 32.40 & 5.40 \\
$\mathrm{M}_{1}$ & 34.35 & 5.73 \\
$\mathrm{M}_{2}$ & 33.76 & 5.63 \\
$\mathrm{M}_{3}$ & 35.00 & 5.83 \\
\hline
\end{tabular}

Source: Data processed (2015).

The relationship between the composition of MOL with the root length of age 5 MST can be seen in Figure 3.

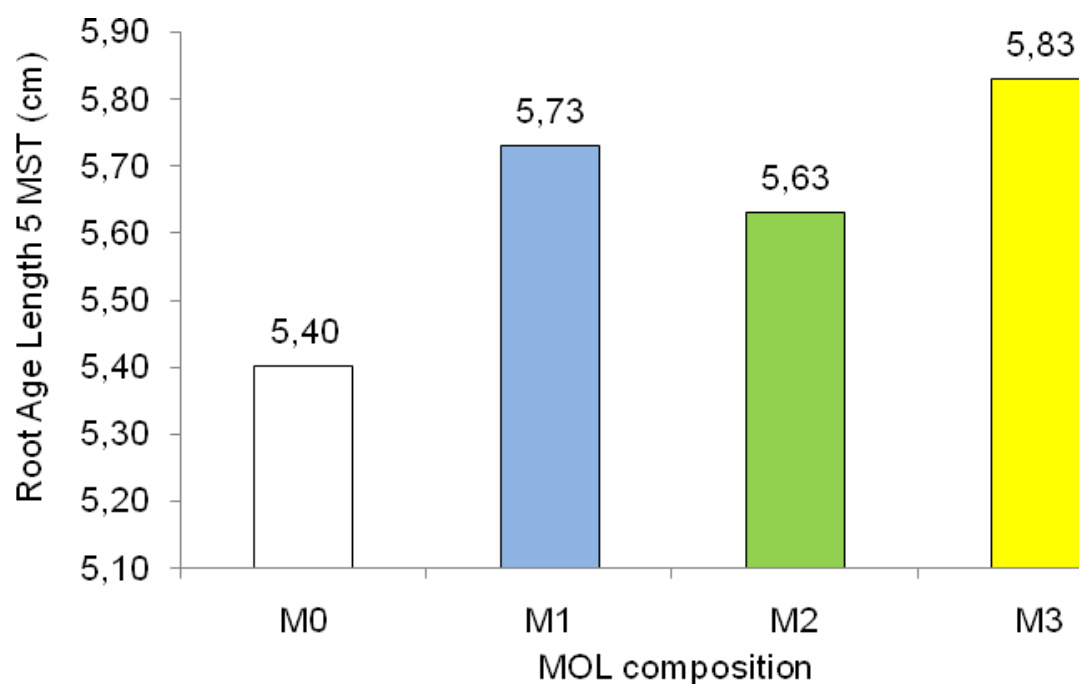

Figure 3. Relationship Diagram between MOL Composition and Root Length of Lettuce Age 5 MST

From the picture above it appears that the M3 treatment is the one that has the longest root, which is $5.83 \mathrm{~cm}$.

\subsection{Wet Harvest Weight (g)}

The results of statistical data analysis on the variance list showed that the treatment of various MOL compositions did not significantly affect the wet weight of the lettuce plants.

Table 4. Data on the Effect of MOL Composition on Harvest Wet Weight (g) Age 5 MST

\begin{tabular}{ccc}
\hline Treatment & Total & Average \\
\hline $\mathrm{M}_{0}$ & 132.54 & 22.09 \\
$\mathrm{M}_{1}$ & 122.57 & 20.43 \\
$\mathrm{M}_{2}$ & 94.28 & 15.71 \\
$\mathrm{M}_{3}$ & 142.53 & 23.76 \\
\hline
\end{tabular}

Source: Data processed (2015). 
The relationship between the composition of MOL with the wet weight of lettuce aged 5 MST can be seen in Figure 4.

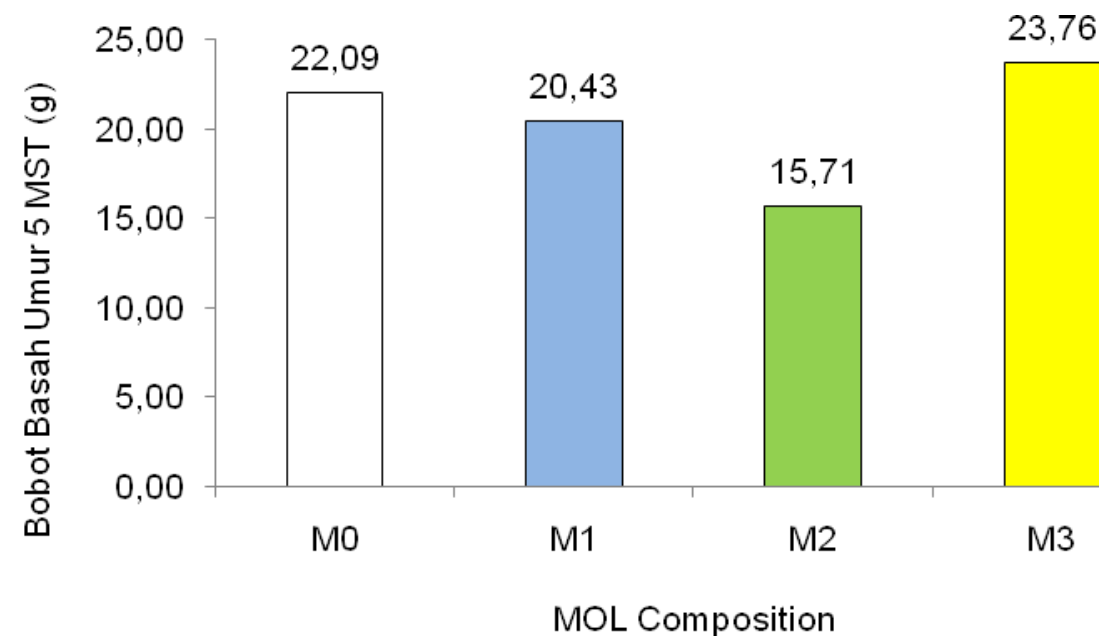

Figure 4. Relationship Diagram Between MOL Composition and Average Wet Weight of Lettuce Age 5 MST

From the picture above it appears that the M3 treatment is the one that has the largest wet weight, which is $23.76 \mathrm{~g}$.

Giving a variety of compositions of MOL in this study, should be able to have a real influence on growth and yield. But in fact the administration of MOL actually has an unreal effect. This is thought to be caused by several factors, including the low concentration of MOL given, namely cc / 1 of water and also the application is given only once, at the age of 2 weeks after planting.

This is consistent with the opinion of Lingga (2007) who said that the application of liquid fertilizer must be the right dose. Doses that are too high or too low can inhibit plant growth and development. Therefore, the application of liquid fertilizer can be given several times to plants.

The results of a study conducted by Parawansa and Ramli (2014) found that the best dose of MOL treatment on sweet potato plant growth was $75 \mathrm{cc} / 1$ compared to $150 \mathrm{cc} / 1$ and $200 \mathrm{cc} / 1$. This shows the dose is too low or too high can be a barrier to plant growth (Lingga, 2007).

Although the treatment of MOL composition showed no significant effect, but visually all parameters can be seen that the treatment of M3 $(1 / 4 \mathrm{~kg}$ papaya $+1 / 4 \mathrm{~kg}$ palm sugar $+2 \mathrm{~L}$ coconut water $+2 \mathrm{~L}$ rice washing water $+1 / 4 \mathrm{~kg}$ maja fruit) is a treatment that is best. This is caused by the content of MOL that varies according to the basic ingredients of the MOL. MOL solution contains macro nutrients (N, P, K, Ca, Mg, and S) and micro (Zn, $\mathrm{Cu}, \mathrm{Mo}, \mathrm{Co}, \mathrm{B}, \mathrm{Mn}$, and $\mathrm{Fe}$ ).

Young coconut water contains nutrients such as potassium, calcium, phosphorus, zinc, sodium, magnesium, vitamins $\mathrm{B}_{3}, \mathrm{~B}_{5}, \mathrm{~B}_{6}$ and vitamins. Papaya fruit contains vitamins A, B, Riboflavin, niacin, C, calcium, phosphorus, potassium, fat, carbohydrates and protein. Rice washing water contains carbohydrates, sugars, proteins, glutein, cellulose, hemicellulose and vitamin B. Maja fruit in the M3 treatment contains fat and flying oil containing linonen. Whereas in $\mathrm{M} 2$ there is the addition of bamboo shoots, where bamboo shoots contain fiber nutrition, riboflavin (vitamin $\mathrm{B}_{2}$ ), thiamine (vitamin $\mathrm{B}_{1}$ ), niacin (vitamin $\mathrm{B}_{3}$ ), phosphorus, potassium, potassium and protein. Thus the nutrients contained 
Budapest International Research in Exact Sciences (BirEx) Journal Volume 2, No 1, January 2020, Page: 1-9 e-ISSN: 2655-7827 (Online), p-ISSN: 2655-7835(Print) www.bircu-journal.com/index.php/birex

emails: birex.journal@gmail.com

birex.iournal.aa@amail.com

in MOL provide different roles in the growth and development of lettuce (Purwasasmita, 2012).

Vegetative growth of plants shows better results on the $\mathrm{M}_{3}$ treatment compared to other treatments, thus affecting the resulting wet weight. According to Lakit (2001), that crop production is highly dependent on the vegetative growth of the plant. The better the vegetative growth of the plant will be in line with the wet weight of the plant the.

\section{Conclusion}

a. The treatment of administering a variety of liquid organic fertilizer MOL statistically has no significant effect on the growth of lettuce (plant height, number of leaves, root length, and wet weight).

b. Visually, the treatment that produces the best growth is the treatment $M_{3}(1 / 4 \mathrm{~kg}$ papaya $+1 / 4 \mathrm{~kg}$ palm sugar $+2 \mathrm{~L}$ coconut water $+2 \mathrm{~L}$ rice washing water $+1 / 4 \mathrm{~kg}$ maja fruit) compared to other treatments.

In order to do further research using higher doses / concentrations so that the results produced are more significant.

\section{References}

Aliksa.2011. Sri Organik Consultant. Kabupaten Tasikmalaya. Jawa Barat.

Arinong, A. Rahman, Vandalisna dan Asni. 2014. Pertumbuhan dan Produksi Tanaman Sawi (Brassica juncea L.) dengan Pemberian Mikroorganisme Lokal (MOL) dan Pupuk Kandang Ayam. Jurnal Agrisistem, Juni 2014 Vol. 10 No. 1.

Ashari.1995. Usahatani Sayur-sayuran Dataran Tinggi.Media Pustaka. Jakarta.

Azis, A., M. Y. Surung,dan Buraerah. 2006. Jurnal Agrisistem. Produksi Tanaman Selada Pada Berbagai Dosis Posidan http://stoppgowa.ac.id/produksi/selada/diIndonesia/Vol.2/No.1/2006.06 Juni 2009.

Ekamaida.2010. Pengelolaan Lahan Pertanian Ramah Lingkungan dengan Sistem Intensifikasi Tanaman PadiMelalui Pemanfaatan Mikroorganisme Lokal dalam Pembuatan Kompos (Studi Kasus di DesaSidodadi Kabupaten Deli Serdang).Tesis.Program Pengelolaan Sumberdaya Alam dan Lingkungan. Universitas Sumatera Utara.

Farhan, Muhammad. 2012. Direktorat Jendral Hortikultura. Produksi Tanaman Sayuran di Indonesia Periode 2003-2007. Depatermen Pertanian. Jakarta.

Gomez, K.A. and A.A. Gomez.1995. Prosedur Satatiska untuk Penelitian Pertanian.Diterjemahkan oleh Endang Sasudin dan Justika S. Bahasyah.UI-Press. Jakarta.

Hakim, N., M.Y. Nyakpa, A.M. Lubis, S.G. Nugroho, M.R. Saul M.A. Diha, G.B. Hong dan H.H. Bailey. 1986. Dasar-dasar Ilmu Tanah.Universitas Lampung.Lampung.

Haryanto, E., T. Suhartini dan E. Rahayu.2003. Sawi dan Selada. Penebar Swadaya, Jakarta.

Hastuti, R. 2008. Skripsi.Profil Usaha Tani Selada (Lactuca sativa) Organik di Kelompok Tani Sidomulyo Desa Windujaya Kec. Kedungbanteng Kabupaten Banyumas. Purwokerto.

Hidayat, N. 2010.Aplikasi Pupuk Organik Cair terhadap Produksi Bahan Kering, Kandungan Protein Kasar Rapuh Gajah Varietas Thailand.Jurnal Ilmiah Inkoma Vol. 21 no. 3 Oktober 2010.

Musnamar, I. E. 2005. Pembuatan dan Aplikasi Pupuk Organik Padat. Penebar Swadaya. Jakarta. 
Budapest International Research in Exact Sciences (BirEx) Journal Volume 2, No 1, January 2020, Page: 1-9 e-ISSN: 2655-7827 (Online), p-ISSN: 2655-7835(Print) www.bircu-journal.com/index.php/birex emails: birex.journal@gmail.com birex.iournal.aa@amail.com

Nazaruddin.2003. Komoditi Ekspor Pertanian Tanaman Pangan dan Hortikultura. Penebar Swadaya. Jakarta.

Nurhasanah, Y.S. 2011. Air Cucian Beras Dapat Suburkan Tanaman.Institut Pertanian Bogor. Bogor.

Panudju, T. I. 2011. Pedoman Teknis Pengembangan Rumah Kompos.

Parawansa, Ismaya N.R. dan Ramli. 2014. Mikroorganisme Lokal (MOL) Buah Pisang dan Pepaya terhadap Pertumbuhan Tanaman Ubi Jalar (Ipomea batatas L.). Jurnal Agrisistem, Juni 2014 Vol. 10 No. 1.

Parman, S. 2007. Pengaruh Pemberian Pupuk Organik Cair Terhadap Pertumbuhan dan Produksi Kentang.Laboratorium Biologi Struktur dan Fungsi Tumbuhan. Jurusan Biologi FMIPA. Universitas Diponogoro.

Pracaya.2002. Bertanam Sayuran Organik. Penebar Swadaya. Jakarta.

Pranata, A.S. 2004.Pupuk Organik Cair : Aplikasi dan Manfaatnya. Agromedia Pustaka. Jakarta.

Purwasasmita,M.L.2009.Mikroorganisme Lokal Sebagai Pemicu Siklus Kehidupan Dalam Bioreaktor Tanaman.Seminar Nasional Teknik Kimia Indonesia.

Ricard. 2011. Pembuatan MOL (Mikroorganisme Lokal). http://id.shvoong.com/ exactscinces/agronomy-agriculture/2031453-pembuatan-molmikroorganisme/\#ixzzl ulmSyTK0.Diunduh 9 May 2012.

Rubatzky, V. E. dan M. Yamaguchi.1998. Sayuran Dunia, Prinsip, Produksi dan Gizi, Jilid 2. PenebarSwadaya. Jakarta.

Santi, L.P., Sumaryono, and Didiek H.G. 2006. Evaluasi Aplikasi Biofertilizer EMAS pada Tanaman Jagung di Pelaihari, Kalimantan Selatan.Buletin Agronomi, Vol.35 (1).2007. Departemen Agronomi Hortikultura Fakultas Pertanian. Institut Pertanian Bogor (IPB) dan Perhimpunan Agronomi Indonesia (PERAGI).

Setianigsih, Retno. 2009. Kajian Pemanfaatan Pupuk Oerganik Mikro Organisme Lokal (MOL) dalam Priming, Umur Bibit dan Peningkatan Daya Hasil Tanaman Padi (Oryza sativa L.)Uji Coba Penerapan System of Intensification (SRI).Balai Pengawasan dan Sertifikasi Benih Tanaman Pangan (BPSB) Propinsi Daerah Istimewa Yogyakarta.Diunduh : 4 Maret 2011

Sidauruk, Lamria. 2016. Disain Polikultur Kentang (Solanum tuberosum) Dalam Upaya Menekan Infestasi Hama Myzus persicae Sulzer Pada Sistem Pertanian Organik.Disertasi. Universitas Sumatera Utara. Medan.

Soekartawi, 2003. Prinsip Ekonomi Pertanian. Rajawali Press. Jakarta.

Sunarjo, H.2003. Bertanam 30 Jenis Sayuran. Penebar Swadaya. Jakarta.

Toetoet. 2007. Manfaat Selada. http://www.migroplus.com/brosur/nudidaya selada/manfaat.06 Juni 2009.

Wahyudi, J. 2005. Selada, Solusi Tempat untuk Sehat. hhtp://www.indonesia.com/intisari/flona-11.html

Warsito, 2004. Tanaman Hortikultura.Penebar Swadaya. Jakarta.

Widodo, dkk. Budidaya Tanaman Selada Daun (Lactuca sativa) di Kelompok Tani Manunggal Sambi, Pakembinangun, Pakem Sleman, Yogyakarta. Available at http://idjurnal.blogspot. com/2010/08/budidaya-tanaman-selada-daunlactuca.html (Varified 28 Desember 2010). 